\title{
Problem-solving Skills of U20 FIFA World Cup Volunteers
}

\author{
Mustafa BAŞ \\ Karadeniz Technical University, Trabzon, Turkey \\ Hayri AYDOĞAN \\ Recep Tayyip Erdoğan University, Rize, Turkey
}

\begin{abstract}
Federation International Football Association (FIFA) U20 World Cup was held in Antalya, Bursa, Gaziantep, İstanbul, Kayseri, Rize, and Trabzon on June 21-July 13, 2013. The purpose of the current study is to investigate the problem-solving skills of the volunteers serving different duties in FIFA U20 World Cup. The participants of the study consist of 190 females and 485 males, totally 675 volunteers taking the basic volunteer training. In order to investigate the problem-solving skills of the participants, problem-solving inventory (PSI) developed by Heppner and Petersen was employed. In the analysis of the collected data, Mann-Whitney $U$ test and independent samples $t$-test were utilized. It was determined that the participants' problem-solving skills vary significantly depending on their cultural background, educational status, and gender.
\end{abstract}

Keywords: sports organizations, volunteering, problem-solving, 2013 FIFA U20 World Football Championship

\section{Introduction}

Occupying an important place in the management process of sports organizations, human resources management is a field that can yield important findings for institutional development as well as for organizational success. For the construction of a problem-free organization, management techniques used within organizations should be carefully planned. Thus, strategies used for the management of both paid and unpaid voluntary human resources are of great importance.

Human resources managers of sports organizations conduct their work on two different target populations that are paid human resources and unpaid voluntary human resources. The need for qualified human resources for the planning of organizations is met, considering the financial conditions, through paid workforce and voluntary human resources. Participation of volunteers in organizations is gaining greater importance due to economic and human resources related reasons and it has become an important field of research in the management of sports organizations in recent years.

Federation International Football Association (FIFA) U20 World Football Championship, one of the biggest sports organization of the history of Turkey, was first hosted by Turkey in different cities of the country, such as İstanbul, Bursa, Antalya, Kayseri, Gaziantep, Trabzon, and Rize on June 21-July 13, 2013. For this organization to be perfect, great efforts were invested for the arrangement of its human resources as well as its infrastructure and technical aspects.

The most important role is played by volunteers for sports organizations to be successful. Big organizations

Mustafa BAŞ, Ph.D., assistant professor, School of Physical Education and Sports, Karadeniz Technical University. Hayri AYDOĞAN, Ph.D., assistant professor, School of Physical Education and Sports, Recep Tayyip Erdoğan University. 
can achieve their targets with the help of volunteers. Volunteers working in international sports organizations occupy positions as important as the ones occupied by professionals (Sertbaş et al., 2004). Volunteers who are assigned to duties within the organization on the basis of their personal qualifications make important contributions to the success of the organization. During the activities within the organization, volunteers are continuously in contact with "clients." Thus, they need to meet clients' needs and wishes. However, volunteers are not paid in return for their efforts and work. Volunteers spend their time and energy and utilize their talents and skills for the organization to run smoothly. Therefore, organization committees carefully examine the motives, qualifications, needs, and expectations of volunteers, so that they can make optimal use of them during the organization (Auld \& Cuskelly, 2001).

There are six factors motivating people to be volunteers, which are altruism, sense of social and ethical responsibility, sense of egoistic obligation, desire to gain new experiences, wish to spend leisure time, and to develop their personal talents (Griffiths \& Armour, 2012). The importance of volunteers for sports organizations has been increasing in recent years. Volunteers have become an important part of sports organizations and an important element of sports management (Yu-fang, 2004). Particularly, in Olympic Games in which the number of athletes is high, a large number of volunteers are needed. In many countries, involvement of volunteers in sports organizations is viewed to be very important for the success of the organization (Nichols et al., 2003).

\section{Literature Review}

Sports organizations involve the movement of athletes and spectators, bring about some economic side-effects, last for a limited time period, and are generally subject to intense media interest (Jun, 2005). In addition to their psychological, political, and administrative effects, organizations have economic, social, and ecological results (Hai, 2003). Sportive competitions and the services required by them, such as transportation, technical infrastructure, and food and beverage services are at the center of the large organizations, such as the Olympics. The arrangements are not limited to these and some other activities, such as festivals, can also be organized. Therefore, involvement of volunteers in such arrangements as well as sports activities is of great importance for the success of the organization as a whole (Nichols \& Ojala, 2009).

There are many reasons behind volunteers' willingness to take part in such organizations. Objectives, such as developing personal skills and utilizing them in the organizational process, making a contribution to the success of the organization and to the social development, being appreciated by the society, and being successful in professional life lead individuals to be volunteers in sports organizations.

From their birth onwards, human beings have to respond to stimuli coming from their external and internal worlds. Each stimulus can result in a problem situation of the individual. The success of the individual in coping with this problem situation positively affects his/her self-confidence and personality (Kiremitçi, 2012).

In this regard, first, the definition of the concept of problem should be given. There are different definitions of the concept of problem in literature. Kalayc1 (2001) defined it as "a state of tension, imbalance, incompliance, and uncertainty." According to the Turkish Language Association Dictionary (2013), the concept of problem is defined as an issue that should be learned through investigation and solved by thinking and concluded.

According to Morgan (1999), problem is "a state of conflict in which the individual encounters an obstacle preventing him/her from reaching a target." Bingham (1998), on the other hand, defined it as an obstacle standing against the forces accumulated by the individual to accomplish an objective. Heppner and Krauskopf 
(1987) explained the concept of problem as problems and psychological disturbances faced in the daily life. Problem is defined in general as a state hindering people from reaching their targets, posing some challenges for them, and arousing a sense of distress in them. Encountered and solved once, the problem situation is not considered to be a problem when faced once more. There are various types of problems, such as long-term, short-term, simple or complex, emotional, economic, and physical. Different types of problems may combine with each other and yield big complex problems (Cüceloğlu, 2003).

Problem-solving requires time, effort, energy, and practice. It is also multi-dimensional as it is related to the individual's needs, objectives, values, beliefs, skills, habits, and attitudes and entails the integration of various elements, such as creative thinking, intelligence, emotions, willpower, and action (Kiremitçi, 2012). Problem-solving is closely associated with the psychological compliance of the individual, his/her self-confidence, effectiveness of his/her communication skills, his/her decision-making styles, and academic and social self-esteem (Yerli, 2009). It is known that activities performed voluntarily enhance these personal characteristics and have positive effects on the utilization of decision making and other skills. Problem-solving entails the selection of appropriate actions to reach a goal, construction of alternative solutions to difficulties experienced, evaluation of the alternatives, selection of the best alternative, and a systematic process of intervening with undesired situations (Evans, 1991). According to another definition, problem-solving is a cognitive and behavioral process, involving the construction of effective response alternatives for a problematic situation and selection of the best alternative from among the possible options (D'Zurilla \& Goldfried, 1971).

Mark (1994) stated that the stages to be followed during the process of problem-solving are defined by John Dewey as follows: Perception of a challenge, specification of the challenge, proposal of alternative solutions, evaluation of the weakness and strengths of the proposed solutions, and testing of the solution. Ulupınar (1997) found that socio-demographic features, such as age, marital status, family attitudes, living alone, way of defining himself/herself, and professional status are effective in identifying the source of the problems, the problems experienced, attitudes and behaviors adopted to solve the problem, self-evaluation of the performance in problem-solving, and perception of one's own problem-solving skills.

Problem-solving skill can be defined as an ability to develop analysis and identification strategies for different types of problems, to design a method for the selected strategy, and to evaluate the outcomes (Mettas \& Constantinou, 2006). This skill enables individuals to adapt to social life and to make contributions to social development (Erden, 1986). In sports organizations, this skill has a particular importance for the effective management and maintenance of the organization. Anderson (1980) defined problem-solving primarily as focusing on the target by using cognitive methods. In this regard, what is first expected from the worker is to focus on the problem and to find a solution by using his/her cognitive skills. It is reported that when compared to individuals who can effectively solve their problems, individuals who cannot effectively solve their problems experience more anxiety and lack of self-confidence, are less efficient in understanding others' expectations, and have more emotional problems (Heppner \& Baker, 1997).

Determination of the problem-solving skills of volunteers is of great importance for the success of any organization, because volunteers are people selected to serve some functions in the organization according to their knowledge and skills. Thus, the determination of the problem-solving skills of the volunteers recruited in FIFA U20 World Football Championship might yield findings that will increase the success of future organizations. In addition to this, in the relevant literature, it is reported that individuals doing regular exercise can establish better relationships (Johnson, 1966; Siedentop \& Van der Mars, 2004) and can be more successful 
in resolving conflicts and problems (Sözen, 2012; Wright, Burrows, \& MacDonald, 2004). Thus, the current study aims to investigate the problem-solving skills of the volunteers.

\section{Method}

The method of the current research is the field research aiming to investigate events and phenomena in their natural settings and for this purpose, survey model was employed in the study. Survey model aims to describe a situation as it is. The subject, individual, or object under investigation is defined in its own conditions and as it is. No effort is made to change or affect it. What is important is the observation and specification of what is wanted to be known (Karasar, 2005).

\section{Study Group}

The participants of the study are 1,000 volunteers recruited in the cities of Antalya, Bursa, Gaziantep, İstanbul, Kayseri, Rize, and Trabzon for U20 World Football Championship. A questionnaire was administered to 780 participants and 675 of the questionnaires were found to be suitable for analysis. All of the volunteers participating in the current study underwent basic volunteering training, team-work training, and briefing about their units.

\section{Data Collection Instruments}

\section{Problem-Solving Inventory (PSI)}

Measuring the individual's self-perception of his/her own problem-solving skills, this inventory was developed by Heppner and Peterson (1989). This is a Likert-type scale consisting of 35 items whose response alternatives range from " $1=\mathrm{I}$ never behave like this" to " $6=\mathrm{I}$ always behave like this." The scoring is performed in a reverse order for negative items. The higher the score taken from the scale is, the lower the individual's perception of his/her own problem-solving skills is. The score that can be taken from the inventory varies between 32 and 192. Low scores indicate a higher efficiency in problem-solving and high scores indicate a lack of efficiency in finding effective solutions to problems (Taylan, 1990). Turkish adaptation study of the scale was performed by Savaşır and Şahin (1997). For the current study, internal consistency of the scale was calculated with Cronbach Alfa statistics and found to be $\alpha=0.78$.

\section{Data Collection}

The inventory was administered to the participants during their spare time while the organization was still proceeding. First, the participants were informed about the inventory, and then asked to complete it. Then, the inventories were collected and examined by the researchers and 105 inventories found to be uncompleted or erroneous were excluded from the analysis.

\section{Data Analysis}

In the analysis of the collected data, descriptive statistics standard deviation, independent samples $t$-test, and Mann-Whitney $U$ test were used and the significance level was set to be 0.05 .

\section{Findings}

Mean, standard deviation, minimum and maximum values related to PSI are presented in Table 1.

Kolmogorov-Smirnov test was used to determine the normality of the data distribution and Levene's test was used to assess the equality of variances before analyzing whether there is a statistical difference in the 
mean scores of PSI, according to variable of being a referee in different sport branches. The analysis yielded that data distribution related to PSI is normal $(p>0.05)$. However, variances related to data do not show homogeneous distribution $(F=35.153 ; p=0.000)$. The result of Mann-Whitney $U$ test, which is a non-parametric test, is shown in Table 2, subsequent to the fact that parametric test assumptions were not met.

Table1

Volunteers' PSI Values

\begin{tabular}{llllll}
\hline Score & $N$ & Minimum & Maximum & $\bar{X}$ & $S D$ \\
\hline PSI & 675 & 56 & 125 & 93.28 & 8.47 \\
\hline
\end{tabular}

Table 2

Mann-Whitney U Test Result According to Variable of Being a Referee in Different Sport Branches

\begin{tabular}{lllllllll}
\hline & $N$ & $\begin{array}{l}\text { Mean } \\
\text { rank }\end{array}$ & \multicolumn{2}{l}{ Sum of ranks } & Mann-Whitney $U Z$ & $p$ & Levene's $F$ & $p$ \\
\hline Volunteers & 675 & 77.21 & 8103.00 & 2278.00 & -5.357 & $0.000^{*}$ & 33.221 & $0.000^{* *}$ \\
\hline
\end{tabular}

Notes. ${ }^{*} p<0.05 ;$ and ${ }^{* *} p<0.05$.

When examined Table 2, Levenes' test result shows that variances do not distribute as homogeneous $(p<0.05)$ and findings related to Mann-Whitney $U$ test yield a statistically significant difference in favor of volunteers $(p$ $<0.05)$. High scores obtained from PSI show that one cannot find effective solutions for the problems faced.

\section{Discussion and Conclusion}

When the mean scores of PSI are analyzed, it can be said that volunteers got moderate points. In his study, Kaya (1992) found high correlations among perceived problem-solving levels of university students and level of self-respect, level of continuity of self-values, level of depressive affect, level of confidence to people, level of criticism sensitivity, level of psychosomatic symptom, and level of feeling menace in interpersonal relationship. Wright, Burrows, and MacDonald (2004) reported that athletes having serious injuries can overcome this period more easily by using effective problem-solving skills. The role of problem-solving skills in dealing with internal and external problems encountered during the period of recovery from an injury was found to be very significant.

Öztürk, Koparan, and Efe (2009) emphasized that a good sport manager must have more humanity proficiency as much as management proficiency. They further stated that a manager must love sport, athletes, and the other sport employees, must determine beforehand the target of contribution to sport, must read and follow the broadcastings related to sport, and must improve himself/herself. As a volunteer, worker also must follow the suggestions given above and be receptive to the modernity related to sport. They must have good relationships with the other employees and athletes; must be honest and hardworking; must have the best education, if possible; must know at least one foreign language or try to learn; must prefer country expediencies to their expediencies; must be a good organizer; must give enthusiasm and inspiration group members and must have a good working motivation; must organize the targets according to situation; must be careful while distributing responsibilities; must make difficult decisions; and must be a good negotiator.

Türkçapar (2009) found that the problem-solving mean score of the students from the school of physical education does not vary significantly depending on variables, such as their monthly income levels, social milieu, and most popular activities they are engaged in their spare time, but varies significantly depending on their 
gender and grade levels. D'Zurilla and Goldfried (1971) concluded that undergraduate students educated within the framework of social problem-solving model, when compared to the control group students, produce more effective alternatives to their problems and during the solution of these problems, their auto-control increases, and thus they can control their anger better and make less use of carelessness style.

Öztürk, Koparan, and Efe (2008) conducted a study with the participation of individuals engaged in boxing and found that these individuals possessed medium level of problem-solving skill and with their decreasing level of recklessness and their problem-solving skills were improved. Johnson and Johnson (2004) carried out a meta-analysis and reported that while the students taking part in a problem-solving skill training used to capitalize on the strategies of win-or-lose, resorting to power and retreating before the training, they showed a tendency to employ problem-solving process after the training. Pakaslahti (2002) found that the problem-solving skill mean score of the girls was higher than that of the boys and the difference was significant. Canan and Ataoğlu (2010) stated that individuals doing regular exercise have a more optimistic viewpoint of life and accordingly they have stronger problem-solving skills.

Chang (1998), Elliot, Godshall, Shrout, and Witty (1990) reported that individuals having higher levels of problem-solving skills are more successful in academic and social life. Greening (1997), Joffe, Dobson, Fine, Marriage, Glenn, and Haley (1990) found the PSI perceptions of the students not using tobacco and alcohol were better than those of the students using tobacco and alcohol and the difference between these two groups was significant. Deficits in problem-solving skills might lead to problems, such as substance abuse among young people. Kruger (1997) pointed out that individuals not only need to possess problem-solving skills, but they also need to rely on their skills. Hoffman and Spatariu (2008) found that there is a positive significant relationship between adolescents' social and emotional self-efficacy beliefs and their problem-solving skills. Research on children revealed that as they grow up, childrens' social problem-solving skills become more effective (Battistich et al., 1989).

Research on volunteers (Nichols et al., 2003; Jun, 2005; Hai, 2003; Nichols \& Ojala, 2009) showed that the success of sports organizations is directly related to the performance of these people. Social skills, such as problem-solving skills possessed by these people are of great importance for the success and efficiency of the organization.

As a conclusion, the current study revealed that the volunteers' problem-solving skills vary significantly depending on their cultural background, educational status, and gender. Parallel to this finding, the national and international literature shows that people with developed problem-solving skills are physically healthier and can make better cognitive evaluation of occurrences and situations. It is believed that it is particularly effective on individuals' problem-solving skills in the developmental period. Considering that the athletes in U20 are in their late adolescence, it is expected that the athletes actively engaged in sports activities in this period should have effective problem-solving skills. It is thought that individuals' willingness also has an effect on these results.

In light of the findings of the current study, some suggestions can be made. In sports organizations, like $\mathrm{U} 20$, the performance of volunteers is of great importance. It was revealed that the volunteers can play a very important role for the success of the organization. In this regard, it is suggested that more research should be directed towards volunteers in Turkey. Training programs should be developed for volunteers to take part in football organizations, and thus, more importance should be attached to the training of such volunteers particularly by the Turkish Football Federation. 


\section{References}

Auld, C., \& Cuskelly, G. (2001). Behavioural characteristics of volunters: Implications for community sport and recreation organisations. Australian Parksand Leisure, 4(2), 29-37.

Alberti, R. E., \& Emmons, M. L. (1970). Your perfect right: A guide to assertive behavior. San Louis Obispo, USA: Impact Publisher.

Anderson, J. R. (1980). Cognitive psychology and its implications (p. 119). San Fransisco, USA: Freeman.

Battistich, V., Solomon, D., Watson, M., Solomon, J., \& Schaps, E. (1989). Effects of an elementary school program to enhance prosocial behavior on children's cognitive-social problem-solving skills and strategies. Journal of Applied Developmental Psychology, 10(2), 147-169.

Bingham, A. (1998). Developing problem solving skills in children. (A. F. Oğuzkan, Trans.). İstanbul: M.E.B. Publications.

Canan, F., \& Ataoğlu, A. (2010). The influence of sports on anxiety, depression, and perceived problem solving ability. Anatolian Journal of Psychiatry, 11(38), 38-48.

Chang, E. C. (1998). Hope, problem-solving ability, and coping in a college student population: Some implications for theory and practice. Journal of Clinical Psychology, 54(7), 953-962.

Cüceloğlu, D. (2000a). Human and behavior. İstanbul: Remzi Publications.

D’Zurilla, T. J., \& Goldfried, M. R. (1971). Problem solving and behavior modification. Journel of Abnormal Psychology, 78(1), 107-126.

Elliot, T. R., Godshall, F., Shrout, J. R., \& Witty, T. E. (1990). Problem-solving appraisal, self-reported study habits, and performance of academically at-risk college students. Journal of Counseling Psychology, 37(2), 203-207.

Evans, J. R. (1991). Creative thinking: In the decision and managemet sciences. Ohio: Sought-Western Publishing Company.

Greening, L. (1997). Adolescent stealers' and nonstealers' social problem-solving skills. Adolescence, 32(125), 51-55.

Griffiths, M., \& Armour, K. (2012). Mentoring as a formalized learning strategy with community sports volunteers. Mentoring \& Tutoring: Partnership in Learning, 20(1), 151-173.

Hai, R. E. N. (2003). Olympic volunteers and university students. Shanghai Sports Science Research, 1, 10.

Heppner, P. (1978). A review of the problem solving literature and it's relationships to the counseling process. Journal of Counseling Psychology, 25(5), 366.

Heppner, P. P., \& Krauskopf, C. J. (1987). The integration of personal problem solving processes within counseling. The Counseling Psychologist, 15, 371-447.

Heppner, P. P., \& Petersen, C. H. (1989). The development and implications of a personal problem-solving inventory. Journal of Counseling Psychology, 29(1), 66-75.

Heppner, P. P., \& Baker, C. E. (1997). Applications of the problem solving inventory. Measurement and Evaluation in Counseling and Development, 29(4), 229-241.

Hoffman, B., \& Spatariu, A. (2008). The influence of self-efficacy and metacognitive prompting on math problem-solving efficiency. Contemporary Educational Psychology, 33(4), 875-893.

Johnson, P. B. (1966). Physical education: A problem solving approach to health and fitness: A textbook for men and women. California: Holt, Rinehart and Winston.

Joffe, R. D., Dobson, K. S., Fine, S., Marriage, K., Glenn, Haley. (1990) Social problem-solving in depressed, conduct-disordered, and normal adolescents. Journal of Abnormal Child Psychology, 18(5), 565-575.

Johnson, D. W., \& Johnson, R. T. (2004). Implementing the teaching students to be peacemakers program. Theory into Practice, 43(1), 68-79.

Jun, A. I. (2005). Training system for sports volunteers in China. Journal of Physical Education, 2, 40.

Kabaday1, R. (1992). Problem solving process, dimensions and in need of education. In Teachers World (Vol. 146, pp. 32-33). Ankara: Nüve Printing Press.

Kalayci, N. (2001). Problem solving and applications in the social sciences. Ankara: Gazi Bookstore.

Karasar, N. (2005). Scientific research method (15th ed.). Ankara: Nobel Release Distribution.

Kaya, N. (1992). Relations between Ondokuz Mayis University problem solving skills and self-esteem of students (pp. 118-119) (Unpublished Master's thesis, Institute of Social Sciences, Ondokuz Mayıs University, Samsun).

Kiremitçi, O. (2012). Problem solving method with adjusted effect of physical education course problem solving skills and the relationship metacognitive awareness (Unpublished Ph.D. thesis, Institute of Health Sciences, Ege University, İzmir).

Kruger, L. J. (1997). Social support and self-efficacy in problem solving among teacher assistance teams and school staff. The Journal of Educational Research, 90(3), 164-168. 
Mark, A. R. (1994). Problem finding, problem solving, and creativity. New Jersey, N.J.: Ablex Publishing Corporation Norwoord.

Mettas, A., \& Costantinau, C. (2006). The technology fair: A project-based learning approach for enhancing problem-solving skills and interest in design and technology education. International Journal of Technology and Desing Education, 18(1), $79-100$.

Morgan, C. T. (1999). Introduction to psychology. (H. Arıc1, Trans.). Ankara: Meteksan Publications.

Nichols, G., \& Ojala, E. (2009). Understanding the management of sports events volunteers through psychological contract theory. VOLUNTAS: International Journal of Voluntary and Nonprofit Organizations, 20(4), 369-387.

Nichols, G., Taylor, P., James, M., King, L., Holmes, K., \& Garrett, R. (2003). Pressures on sports volunteers arising from partnerships with the central government. Loisir et Societe (Society and Leisure), 26(2), 419-430.

Öztürk, F., Koparan, Ş., \& Efe, M. (2008). Solving the problem of active football referees and determination assertiveness levels in Bursa. Spormetre Journal of Physical Education and Sport Sciences, 4(2), 49-58.

Öztürk, F., Koparan, Ş., \& Efe, M. (2009). Examination of demographic characteristics, assertiveness, and problem solving skills of youth and sport administration province sport office managers. E-Journal of New World Sciences Academy Sport Sciences, 4(2), 30-36.

Pakaslahti, L. (2002). Relationships between adolescent prosocial problem-solving strategies, prosocial problem-solving strategies, prosocial behaviour, and social acceptance. International Journal of Behavioral Development, 26(2),137-144.

Savaşır, I., \& Şahin, H. N. (1997). Cognitive behavioral therapy in the assessment: Frequently used scales (pp. 79-85). Ankara: Turkish Psychological Association Publications.

Sertbaş, K., Atalı, L., Gönener, A., \& Taşkıran, Y. (2004). Sports volunteer organization human resources, case study for Turkey. Ege University, Journal of Performance, 10(1), 21.

Siedentop, D., \& Van der Mars, H. (2004). Introduction to physical education, fitness, and sport. New York, N.Y.: McGraw-Hill.

Sorias, O. (1986). Social skills and assessment methods. Journal of Psychology, 5(20), 25-26.

Sözen, H. (2012). The effect of physical education and sports school training on problem-solving skills of the athletes. Procedia-Social and Behavioral Sciences, 46, 4186-4190.

Taylan, S. (1990). Heppner laid the application of problem-solving inventory, security, and validity studies (Unpublished master's thesis, University of Ankara, Ankara).

Turkish Language Association Dictionary. (2013). Ankar: Turkish Language Institute Publications.

Türkçapar, Ü. (2009). Problem-solving skills in relation to some variables of the students studying in the school of physical education. Ahi Evran University Kırşehir Faculty of Education Journal, 10(1).

Ulupinar, S. (1997). Effect of nursing education students' problem-solving skills (Ph.D. thesis, Institute of Health Sciences, Istanbul University, İstanbul).

Wright, J., Burrows, L., \& MacDonald, D. (2004). Critical inquiry and problem-solving in physical education. London; New York: Psychology Press; Routledge Taylor \& Francis Group.

Yerli, S. (2009). Primary and secondary schools of leaders in problem-solving skills, emotional intelligence and relationship between "the Anatolian side of Istanbul case" (Unpublished Master's thesis, Institute of Social Sciences, Maltepe University, İstanbul).

Yu-fang, S. O. N. G. (2004). A study on value of olympic games' volunteers. Journal of Xi'an Institute of Physical Education, 4, 4. 